\title{
Dynamic changes in soil chemical properties and microbial community structure in response to different nitrogen fertilizers in an acidified celery soil
}

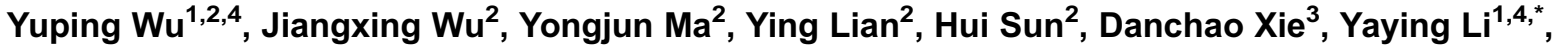 \\ Philip C. Brookes ${ }^{5}$, Huaiying Yao ${ }^{1,4}$ \\ 1 Key Laboratory of Urban Environment and Health, Institute of Urban Environment, Chinese Academy of Sciences, Xiamen 361021, \\ China \\ 2 Ningbo Agriculture Bureau, Ningbo 315012, China \\ 3 Ningbo Institute of Standardization, Ningbo 315040, China \\ 4 Ningbo Urban Environment Observation and Research Station, Chinese Academic Sciences, Ningbo 315830, China \\ 5 College of Environmental and Natural Resource Sciences, Zhejiang Provincial Key Laboratory of Subtropical Soil and Plant Nutrition, \\ Zhejiang University, Hangzhou 310058, China
}

\section{ARTICLE INFO}

\section{Article history:}

Received August 30, 2018

Revised November 7, 2018

Accepted November 10, 2018

Keywords:

Acidified

Calcium cyanamide

Celery

Phospholipid fatty acid

Soil nitrogen

\section{A B S T R A C T}

To determine the effects of different kinds of nitrogen fertilizer, especially high-efficiency slowrelease fertilizers, on soil $\mathrm{pH}$, nitrogen $(\mathrm{N})$ and microbial community structures in an acidic celery soil, four treatments ( $C K$, no $\mathrm{N}$ fertilizer; NR, urea; $\mathrm{PE}$, calcium cyanamide fertilizer; and $\mathrm{SK}$, controlled-release $\mathrm{N}$ fertilizer) were applied, and soil $\mathrm{pH}$, total soil $\mathrm{N}$, inorganic $\mathrm{N}$, and soil microbial biomass $\mathrm{C}$ were analyzed. Phospholipid fatty acids (PLFAs) were extracted and detected using the MIDI Sherlock microbial identification system. The PE treatment significantly improved soil $\mathrm{pH}$, from 4.80 to $>6.00$, during the whole growth period of the celery, and resulted in the highest celery yield among the four treatments. After $14 \mathrm{~d}$ application of calcium cyanamide, the soil nitrate content significantly decreased, but the ammonium content significantly increased. The PE treatment also significantly increased soil microbial biomass $\mathrm{C}$ during the whole celery growth period. Canonical variate analysis of the PLFA data indicated that the soil microbial community structure in the CK treatment was significantly different from those in the $\mathrm{N}$ applied treatments after $49 \mathrm{~d}$ fertilization. However, there was a significant difference $(P<0.05)$ in soil microbial community structure between the PE treatment and the other three treatments at the end of the experiment. Calcium cyanamide is a good choice for farmers to use on acidic celery land because it supplies sufficient $\mathrm{N}$, and increases soil $\mathrm{pH}$, microbial biomass and the yield of celery.

(c) Higher Education Press 2019

\footnotetext{
* Corresponding author

E-mail address: yyli@iue.ac.cn (Y. Li)
}

\section{Introduction}

In the past 30 years, a large of chemical fertilizers and other resources have been used in agriculture (Guo et al., 2010). Some greenhouse vegetable systems even receive $\mathrm{N}$ fertilizer 
at rates of $>4000 \mathrm{~kg} \cdot \mathrm{ha}^{-1} \cdot$ year $^{-1}$ (Ju et al., 2007). High levels of fertilizer inputs cause serious soil acidification problems, with $\mathrm{pH}$ decreases of 0.3 to 0.8 units in greenhouse vegetable systems in China (Guo et al., 2010; Liang et al., 2013; Cai et al., 2015). The production of protons via the nitrification process after urea and ammonium nitrogen fertilization is considered the major driver of soil acidification. Moreover, ammonium can displace base cations $\left(\mathrm{Ca}^{2+}, \mathrm{Mg}^{2+}, \mathrm{K}^{+}, \mathrm{Na}^{+}\right)$ binding to the soil surface and make them enter the soil solution as accompanying ions with the leaching nitrate (Matschonat and Matzner, 1996), reducing their ability to buffer against acidification (Lucas et al., 2011). Soil acidification can lead to deficiencies in phosphorus, potassium, magnesium, and calcium, and the accumulation of aluminum and manganese in soil (Ruan et al., 2012; Tian and Niu, 2015). Moreover, nitrogen fertilizers application suppresses both soil microbial biomass and microbial diversity (Zhou et al., 2017). Recently, a meta-analysis revealed that $\mathrm{N}$ addition decreased the relative abundance of Actinobacteria and Nitrospirae in soil (Wang et al., 2018). This degradation of soil quality reduces productivity and profitability for farmers (Wells et al., 2000). This problem has become a major concern for scientists, agricultural policymakers and farmers (Liang et al., 2013). The Ministry of Agriculture of the People's Republic of China formulated plans to obtain a target of "zero growth" in the amount of chemical fertilizers used on crops by 2020. Many scientists have designed knowledge-based optimum fertilization management practices to increase the efficiency of use of fertilizers (Ju et al., 2007; Yang et al., 2016). Liming (Zhang et al., 2015), manure application (Noble et al., 1996; Cai et al., 2015), and slow-release fertilizer use (Gu et al., 2014) all increase soil pH. Various fertilization modes have been applied during crop cultivation. However, most of the new technologies available to farmers were obtained from fertilizer sellers, and their effects on soil quality were seldom considered.

Celery is a high-value, low-acreage crop that receives high rates of $\mathrm{N}$ fertilizer to maximize yield (El-Sayed et al., 2011). In China, celery is one of the most important vegetables, produced on about 550000 ha with a farm gate value of about US $\$ 10$ billion. Many studies have shown that different $\mathrm{N}$ fertilizers have different effects on soil chemical and biological properties (Marschner et al., 2003; Van der Bom et al., 2018). In this study, three nitrogen fertilization treatments, including urea, calcium cyanamide and a commercial "celery special fertilizer" were compared to determine their effects on soil properties and microbial community structure. The objectives of this study were to select the optimal fertilizer treatment and to understand the underlying microbial mechanisms.

\section{Materials and methods}

\subsection{Study site}

Field work was conducted in Sanqin village, Jiangbei District, Ningbo, China $\left(29^{\circ} 57^{\prime} 57^{\prime \prime} \mathrm{N}, 121^{\circ} 22^{\prime} 59^{\prime \prime} \mathrm{E}\right)$. Farmers have grown rice there for $>20$ years, but the site changed to greenhouse vegetable land in 2012. The total annual precipitation averages $1440 \mathrm{~mm}$ and the annual mean air temperature is $16.1^{\circ} \mathrm{C}$. The field experiment site has an area of $450 \mathrm{~m}^{2}$. Soil chemical and physical properties were: $\mathrm{pH}$ 4.80 (1:2.5 w/v, soil/water), total carbon $28.85 \mathrm{~g} \cdot \mathrm{kg}^{-1}$ soil, total nitrogen $3.56 \mathrm{~g} \cdot \mathrm{kg}^{-1}$ soil, nitrate $\left(\mathrm{NO}_{3}{ }^{-}\right) 14.8 \mathrm{mg} \cdot \mathrm{kg}^{-1}$, ammonium $\left(\mathrm{NH}_{4}^{+}\right) 52.4 \mathrm{mg} \cdot \mathrm{kg}^{-1}$, available $\mathrm{P} 219.0 \mathrm{mg} \cdot \mathrm{kg}^{-1}$ and available $\mathrm{K} 392.9 \mathrm{mg} \cdot \mathrm{kg}^{-1}$.

\subsection{Experimental design}

Twelve study plots were established in a random block design with three replicates. Each plot had an area of $37.5 \mathrm{~m}^{2}$ (length $25 \mathrm{~m}$, width $1.5 \mathrm{~m}$ ). The field experiment was conducted from 23 December 2013 to 10 March 2014. Celery (Apium graveolens Linn.) was cultivated in each plot with a number of 3000 plants. Four treatments were applied: (1) no $\mathrm{N}$ fertilizer (CK); (2) urea (NR); (3) calcium cyanamide (PE); (4) celery special controlled-release fertilizer (SK). Based on the recommended fertilization regime, before planting, all the plots were applied the same amounts of nitrogen, phosphate and potassium fertilizers, with application rates 100 $\mathrm{kg} \mathrm{N} \cdot \mathrm{ha}^{-1}, 90 \mathrm{~kg} \mathrm{P}_{2} \mathrm{O}_{5} \cdot \mathrm{ha}^{-1}$ and $90 \mathrm{~kg} \mathrm{~K} \mathrm{O} \cdot \mathrm{ha}^{-1}$, respectively. The dates of celery transplanting and harvesting were 11 January 2014 and 10 March 2014.

\subsection{Analytical methods}

Soils were sampled on 23 December 2013 (0 d), 6 January 2014 (14 d), 10 February 2014 (49 d) and 10 March 2014 (78 d), respectively. The soil was sieved through a $2.0 \mathrm{~mm}$ mesh, and separated into three parts. The first part was airdried for $\mathrm{pH}$, available $\mathrm{P}$, available $\mathrm{K}$, total $\mathrm{C}$ and $\mathrm{N}$ analysis. The second part was stored at $4^{\circ} \mathrm{C}$ for microbial biomass $\mathrm{C}$ and $\mathrm{N}$ analysis, except that inorganic $\mathrm{N}$ was detected immediately. The third part was freeze-dried for PLFA extraction.

Soil $\mathrm{pH}$ in water was detected at a ratio of 1:2.5 (w/v) using a $\mathrm{pH}$ meter (PE20, Mettler Toledo, Switzerland). Total $\mathrm{C}$ and $\mathrm{N}$ were determined using a CNS Element Analyzer (Vario MAX $\mathrm{C} / \mathrm{N}$; Elementar, Germany). Soil available $\mathrm{P}$ was extracted with $0.5 \mathrm{M} \mathrm{NaHCO}_{3}\left(\mathrm{pH}\right.$ 8.5) (soil: $\mathrm{NaHCO}_{3}=1: 20$ ), then shaken on a horizontal shaker for $30 \mathrm{~min}$, and determined by colorimetry (Bao, 1999). Exchangeable $\mathrm{K}$ was extracted with $1 \mathrm{M} \mathrm{CH}_{3} \mathrm{COONH}_{4}(\mathrm{pH} 7.0)$ (soil: $\mathrm{NaHCO}_{3}=1: 10$ ) and shaken for $30 \mathrm{~min}$, and measured by atomic absorption spectrometry (Bao, 1999). Soil $\mathrm{NH}_{4}{ }^{+}$and $\mathrm{NO}_{3}{ }^{-}$were extracted with $1 \mathrm{M} \mathrm{KCl}$ (soil: $\mathrm{KCl}=1: 10$ ) and shaken for $1 \mathrm{~h}$, and detected colorimetrically using a micro-plate reader (Spectramax M5, Molecular Devices, USA) (Shand et al., 2008).

Soil microbial biomass $\mathrm{C}(\mathrm{MBC})$ analyses was performed using the chloroform fumigation extraction method (Brookes et al., 1985; Wu et al., 1990), and a $\mathrm{K}_{\mathrm{EC}}$ factor of 0.45 was used to calculate MBC. PLFAs were analyzed according to the method of $\mathrm{Li}$ et al. (2016). Approximately $2.0 \mathrm{~g}$ of freeze-dried soil was extracted with a total of $22.8 \mathrm{~mL}$ of 
methanol-chloroform-citrate buffer mixture $(2: 1: 0.8 \mathrm{v} / \mathrm{v} / \mathrm{v}, 0.15$ $\mathrm{M}, \mathrm{pH}$ 4.0). A silic acid column was used to separate the phospholipids from neutral- and glycol-lipids. The phospholipids were methylated by a mild-alkali methanolysis. PLFA methyl esters were identified and quantified by gas chromatography (Column HP 5, 50 m length, $0.2 \mathrm{~mm}$ i.d, $0.33 \mu \mathrm{m}$ film thickness; Agilent Technologies Inc., Santa Clara, USA). The detailed equipment information and running conditions were as described by Thornton et al. (2011). The fatty acid 19:0 was added prior to methylation as an internal standard.

\subsection{Statistical analysis}

All data are the means of three replicates. One-way analysis of variance was performed to test the results, and significant differences $(P<0.05)$ between means was calculated by $t$ test. The PLFA data were expressed in molar percent $(\mathrm{mol} \%)$ for multivariate analyses. After first reducing the dimensionality by principal component analysis (PCA), the absorbance data were assessed by canonical variate analysis (CVA). Multivaritate analyses were conducted using GenStat 16th Edition (VSN International, Oxford, UK), and all the other analyses were performed using DPS v7.05.

\section{Results}

\subsection{Changes in soil chemical properties}

The NR and SK treatments had no significant effect on celery yield. Application of calcium cyanamide (PE) resulted in the highest yield ( $\left.37.5 \mathrm{t} \cdot \mathrm{ha}^{-1}\right)$, which was nearly 1.5 times higher than that in the control (CK) (Fig. 1). Soil pH significantly increased from 4.80 to 6.53 at $14 \mathrm{~d}$ after application of calcium cyanamide (Fig. 2A). The increasing trend lasted until the end of the experiment. At $78 \mathrm{~d}$ after application, soil $\mathrm{pH}$ was 6.16 in the PE treatment, which was much higher than those in the other treatments (Fig. 2A). There was no significant difference in soil $\mathrm{pH}$ among the $\mathrm{CK}, \mathrm{NR}$ and $\mathrm{SK}$ treatments during the whole growth period (Fig. 2A). Soil available $P$ and $K$ significantly increased in the PE treatment at $14 \mathrm{~d}$ after application of calcium cyanamide (Fig. 2B and Fig. 2C). The content of available $P$ was apparently higher in the $C K$ and $P E$ treatments than that in the SK treatment on $49 \mathrm{~d}$ (Fig. 2B). On $78 \mathrm{~d}$, soil available $\mathrm{P}$ contents were not significantly different among the four treatments (Fig. 2B). The available K content showed no significant difference between the four treatments both on $49 \mathrm{~d}$ and $78 \mathrm{~d}$ (Fig. 2C).

The total soil $\mathrm{N}$ content was lowest in the SK treatment during the experiment (Fig. 2D). There was no significant difference in soil total $\mathrm{N}$ in the CK, NR and PE treatments (Fig. 2D). From $14 \mathrm{~d}$ after application of calcium cyanamide, the soil $\mathrm{NO}_{3}{ }^{-}$content significantly decreased in the PE treatment (Fig. $2 \mathrm{E})$. There was no significant difference in $\mathrm{NO}_{3}{ }^{-}$content between the treatments after $49 \mathrm{~d}$ fertilizer application (Fig. 2E). On $78 \mathrm{~d}$, the concentration of $\mathrm{NO}_{3}{ }^{-}$in the SK and NR treatments was much higher than those in the $\mathrm{PE}$ and $\mathrm{CK}$

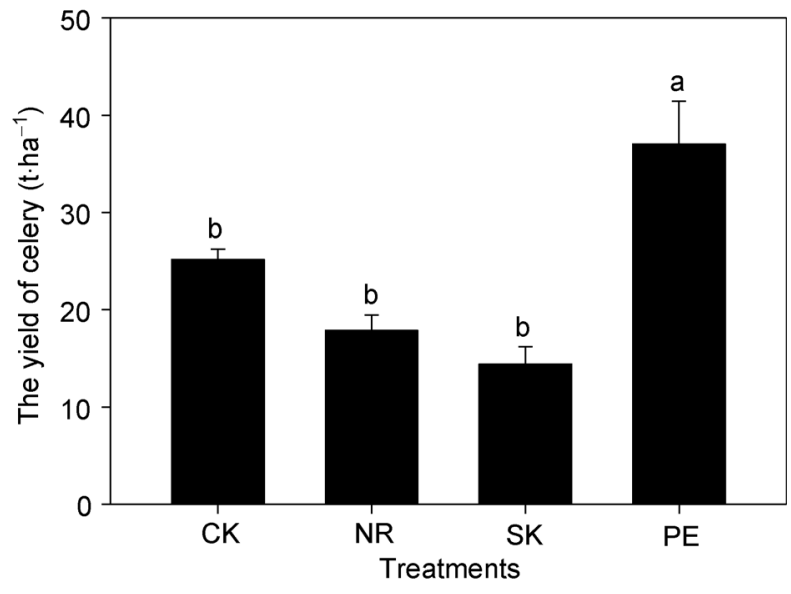

Fig. 1 Effect of different $\mathrm{N}$ fertilizers on celery yield. CK, control; NR, urea; PE, calcium cyanamide fertilizer; SK, celery special fertilizer.

treatments (Fig. 2E). Calcium cyanamide fertilization significantly improved the content of $\mathrm{NH}_{4}{ }^{+}$in soil $14 \mathrm{~d}$ from application (Fig. 2F). On $49 \mathrm{~d}$, there was no significant difference in $\mathrm{NH}_{4}{ }^{+}$content between the treatments (Fig. 2F). The contents of soil $\mathrm{NH}_{4}{ }^{+}$in the SK and PE treatments were significantly higher than those in the NR and $\mathrm{CK}$ treatments at the end of experiment (Fig. 2F).

3.2 Changes in soil microbial biomass and community structure

The PE treatment significantly increased soil microbial biomass $\mathrm{C}$ from $414 \mu \mathrm{g} \mathrm{C} \cdot \mathrm{g}^{-1}$ soil to $633 \mu \mathrm{g} \mathrm{C} \cdot \mathrm{g}^{-1}$ soil after $14 \mathrm{~d}$ fertilization (Fig. 3A). On $49 \mathrm{~d}$, soil microbial biomass $\mathrm{C}$ was significantly higher in the PE, NR and CK treatments than in the SK treatment (Fig. 3A). On $78 \mathrm{~d}$, soil microbial biomass $C$ was the highest in the PE treatment with a content of $794 \mu \mathrm{g}$ $\mathrm{C} \cdot \mathrm{g}^{-1}$ soil, followed by the CK treatment $\left(669 \mu \mathrm{g} \mathrm{C} \cdot \mathrm{g}^{-1}\right.$ soil) and NR treatment (652 $\mu \mathrm{g} \mathrm{C} \cdot \mathrm{g}^{-1}$ soil) (Fig. 3A). Soil microbial biomass $\mathrm{C}$ was lowest in the SK treatment $\left(481 \mu \mathrm{g} \mathrm{C} \cdot \mathrm{g}^{-1}\right.$ soil) (Fig. 3A). Although soil microbial biomass $C$ and total PLFAs were significantly correlated $(P<0.05)$ (Fig. 4$)$, soil microbial biomass calculated by total PLFAs showed no significant differences between the four treatments (Fig. 3B).

The relative abundances of characteristic PLFAs for Gramnegative bacteria, Gram-positive bacteria, Fungal and Actinomycetes were $19.8 \%, 27.7 \%, 2.1 \%$ and $11.0 \%$, respectively. There was no significant difference among the four treatments and the two sampling times (49 $d$ and $78 \mathrm{~d}$ ) (Fig. S1). Canonical variate analysis (CVA) of the PLFA data indicated that the soil microbial community structure in the $\mathrm{CK}$ treatment was significantly different from those in the SK, NR and PE treatments after $49 \mathrm{~d}$ fertilization (Fig. 5A). However when the celery was harvested $(78 \mathrm{~d})$, there was a significant difference $(P<0.05)$ in soil microbial community structure between the $P E$ treatment and the other three treatments (Fig. 5B). The relative concentration of PLFAs 14:0, i14:0, 

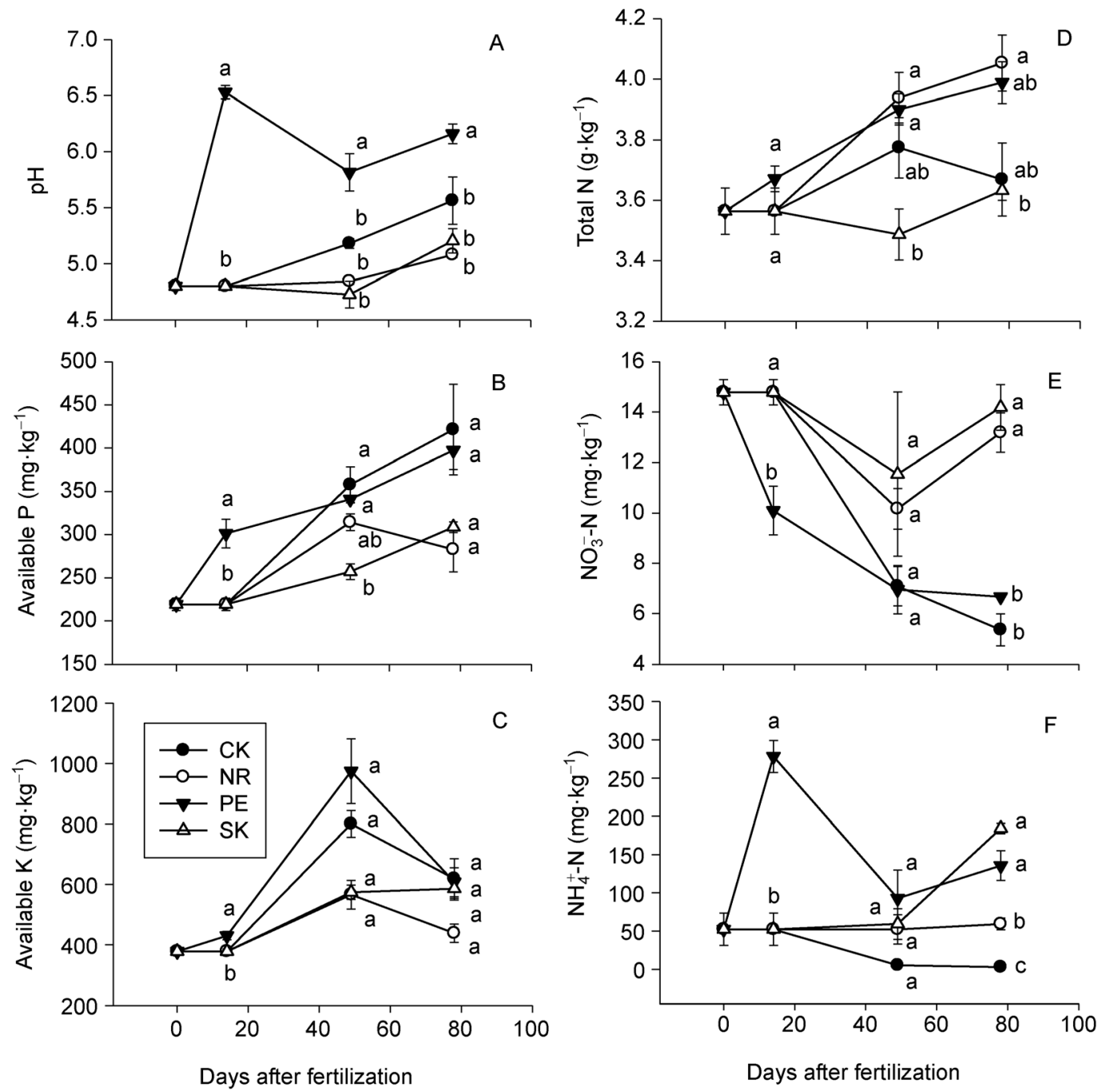

Fig. 2 Temporal variations in (A) $\mathrm{pH},(\mathrm{B})$ available $\mathrm{P},(\mathrm{C})$ available $\mathrm{K},(\mathrm{D})$ total $\mathrm{N},(\mathrm{E}) \mathrm{NO}_{3}{ }^{-}$, and $(\mathrm{F}) \mathrm{NH}_{4}{ }^{+}$in soils over the course of the field experiment. $\mathrm{CK}$, control; NR, urea; $\mathrm{PE}$, calcium cyanamide fertilizer; SK, celery special fertilizer. Bars are standard errors. Different letters (a, $\mathrm{b}$ and $\mathrm{c}$ ) indicate significant differences between different treatments at $P<0.05$.
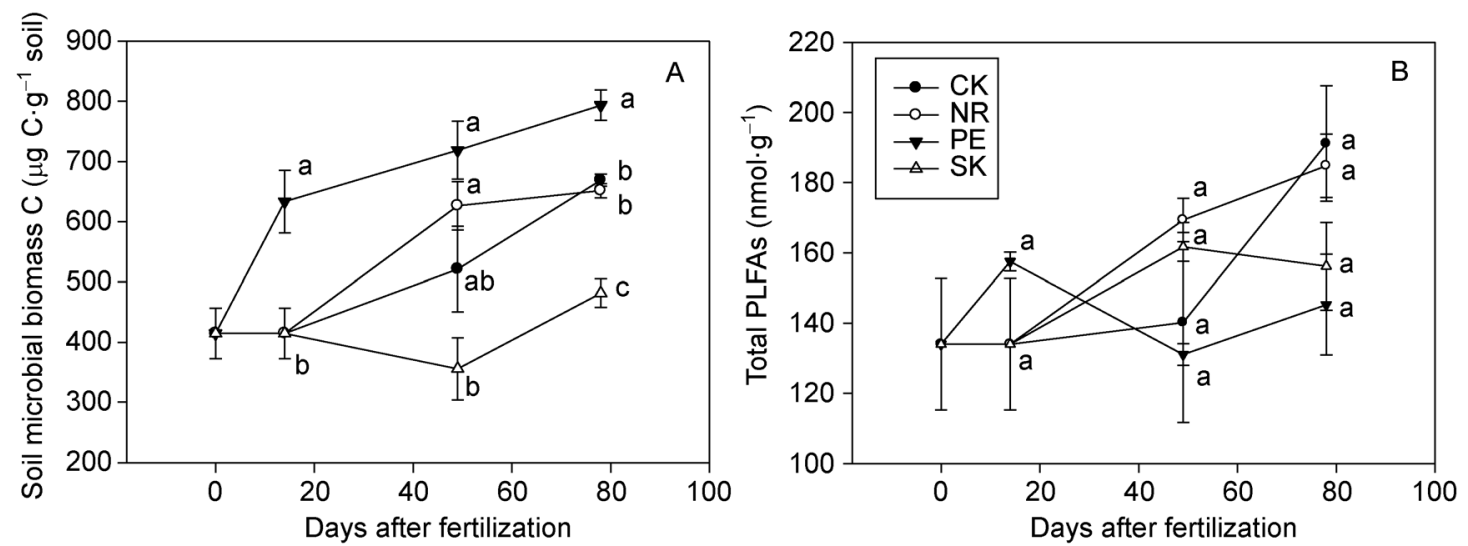

Fig. 3 The variation of soil microbial biomass $C(A)$ and total phospholipid fatty acids (PLFAs) (B). CK, control; NR, urea; PE, calcium cyanamide fertilizer; SK, celery special fertilizer. Bars are standard errors. Different letters $(a, b$ and $c)$ indicate significant differences between different treatments at $P<0.05$. 


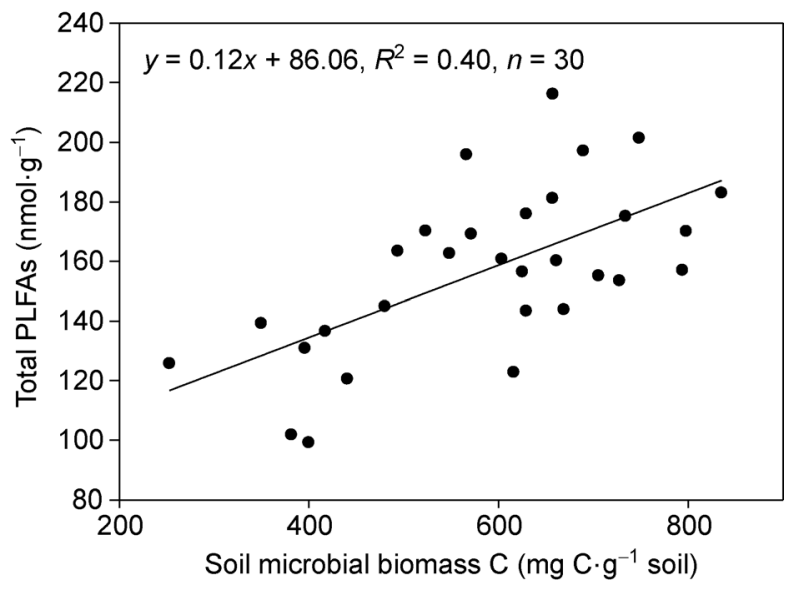

Fig. 4 Biomass C and total PLFAs in soils $\left(R^{2}=0.40, n=30\right)$.

br16:0, $16: 1 \omega 11,16: 1 \omega 7 \mathrm{t}, 18: 1 \omega 7,18: 2 \omega 8,12$ and $18: 2 \omega 6,9$ was higher in the $\mathrm{CK}$ treatment than in the other treatments from $49 \mathrm{~d}$ after fertilization (Fig. 6A). After $78 \mathrm{~d}$ fertilization, the PE treatment had higher concentrations (mol \%) of PLFAs 15:0, 18:0, i15:0, br17:0, 10Me16:0, 10Me17:0 and 10Me18:0, and lower concentrations of PLFAs a15:0, cy17:0, 16:1 $\omega 7 \mathrm{c}$, $16: 1 \omega 5 \mathrm{c}, 18: 1 \omega 7,18: 1 \omega 10$, and $18: 2 \omega 6,9$ compared with the other treatments (Fig. 6B). Analysis of the loading of PLFAs showed that 19:0cy was enriched in the PE treatment, but it had a lower relative abundance of $18: 1 \omega 7$ and $16: 1 \omega 7 \mathrm{c}$.

\section{Discussion}

Calcium cyanamide was one of the first synthetic nitrogenous fertilizers (Crowther and Richardson, 1932). On application to soil, it can be transformed to hydrogen cyanamide, calcium hydroxide and dicyandiamide, hence it has also been widely used as a disinfectant, herbicide, acid modified agent and a slow-release fertilizer (Oh et al., 2006). In our study, the application of calcium cyanamide significantly increased soil $\mathrm{pH}$ by $>1$ unit during the full cultivation period. Oh et al. (2006) also found that calcium cyanamide was effective in stopping soil acidification in tea fields (with an initial pH of 4.5) when applied at almost the same rate as in our study. In traditional liming treatments in China, a large amount of burnt limestone powder $(49.5 \% \mathrm{CaO}$, usually applied at greater than 2000 $\mathrm{kg} \cdot \mathrm{ha}^{-1}$ ) is recommended to obtain increased soil pH (Li et al., 2014). The burnt limestone powder in China is usually not granulated, combined with often humid weather, may result in a proportion of the calcium oxide $(\mathrm{CaO})$ reacting with water $\left(\mathrm{H}_{2} \mathrm{O}\right)$ and carbon dioxide $\left(\mathrm{CO}_{2}\right)$ to produce calcium bicarbonate $\left(\mathrm{CaHCO}_{3}\right)$. This may explain the high application rates of burnt limestone used. Calcium cyanamide would be a better choice to increase soil pH compared with limestone powder.

The content of $\mathrm{NH}_{4}{ }^{+}$in soil significantly increased after calcium cyanamide application in this study, which was consistent with Arora et al. (1987) and Xiao et al. (2018). They found that most of the inorganic $\mathrm{N}$ accumulated in soil after application of calcium cyanamide was present as $\mathrm{NH}_{4}{ }^{+}$, a breakdown product of urea. In soil, calcium cyanamide is hydrolyzed to cyanamide $\left(\mathrm{H}_{2} \mathrm{CN}_{2}\right)$ and slaked lime $\left(\mathrm{Ca}(\mathrm{OH})_{2}\right)$, and then $\mathrm{H}_{2} \mathrm{CN}_{2}$ is converted into urea and dicyanadiamide $\left(\mathrm{C}_{2} \mathrm{H}_{4} \mathrm{~N}_{4}\right)$. Both $\mathrm{H}_{2} \mathrm{CN}_{2}$ and $\mathrm{C}_{2} \mathrm{H}_{4} \mathrm{~N}_{4}$ are well known inhibitors of microbial nitrification (Mukerji, 1932; Amberger and Vilsmeier, 1979; Yamamoto et al., 2014). The addition of calcium cyanamide at a rate of $20 \mathrm{mg} \mathrm{N} \cdot \mathrm{kg}^{-1}$ soil can thoroughly inhibit nitrification activity in soils for at least two months (Arora et al., 1987).

The celery in the SK treatment had the lowest yield, around one-third of that with PE treatment. From $49 \mathrm{~d}$ to $78 \mathrm{~d}$ cultivation, total $\mathrm{N}, \mathrm{NO}_{3}{ }^{-}$and $\mathrm{NH}_{4}{ }^{+}$in the SK treatment increased significantly. The chemical $\mathrm{N}$ applied in the SK treatment was a type of polymer coated fertilizer. The release of nitrogen from the coated fertilizer to the soil might not meet

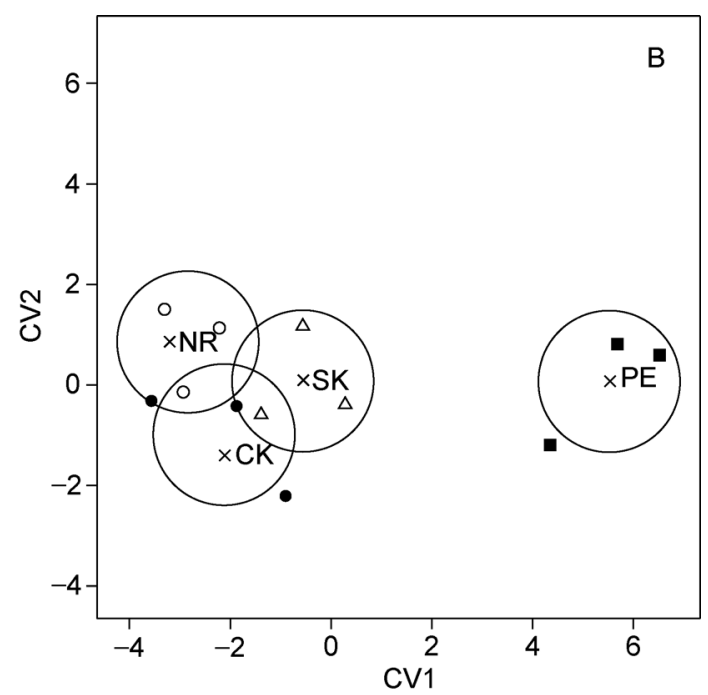

Fig. 5 Plot of ordination of canonical variates (CV). CV1 against CV2 generated by canonical variate analysis of PLFAs after $49 \mathrm{~d}(\mathrm{~A})$ and $78 \mathrm{~d}(\mathrm{~B})$ fertilization. CK, control; NR, urea; PE, calcium cyanamide fertilizer; SK, celery special fertilizer. 


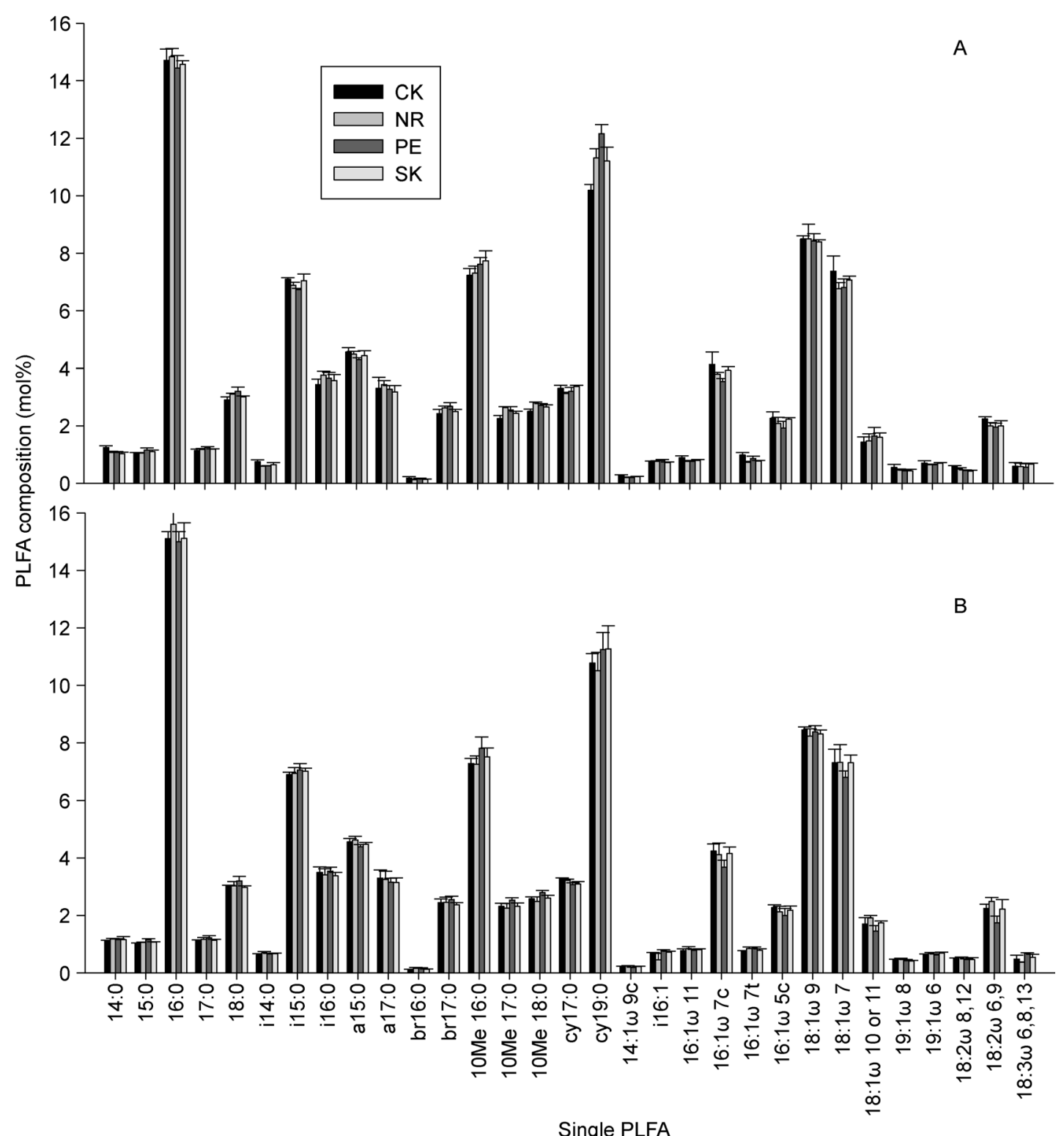

Fig. 6 Relative abundance (mol\%) of PLFAs in four treatments after $49 \mathrm{~d}(\mathrm{~A})$ and $78 \mathrm{~d}(\mathrm{~B})$ fertilization. CK, control; NR, urea; PE, calcium cyanamide fertilizer; SK, celery special fertilizer.

the growth needs of celery, thus resulting in the low yield (Xiong et al., 2010). Although the fertilizer used in the SK treatment was called celery special fertilizer by the distributor (Agrium Advanced Technologies Inc., Canada), it was not a good choice for optimum celery yield, based on our experiment.

Calcium cyanamide can increase soil $\mathrm{pH}$ and release nitrogen, both of which can promote the growth of soil microbes (Zhang et al., 2008; Tian et al., 2009). Xiao et al. (2018) showed that calcium cyanamide could stimulate the population size of soil bacteria, but decrease the population size of fungi. The hydrolysates $\mathrm{H}_{2} \mathrm{CN}_{2}$ and $\mathrm{C}_{2} \mathrm{H}_{4} \mathrm{~N}_{4}$ are toxic to soil microbes (Amberger and Vilsmeier, 1979), but both of them degrade rapidly in soil. Shi et al. (2009) found that the suppressive effect of calcium cyanamide on the soil microbial population was most significant during the first 3 days after application. Thereafter, the populations of bacteria, fungi, and actinomycetes increased gradually.

The inhibitory effects of calcium cyanamide on soil borne diseases have been widely studied (Bourbos et al., 1997; Donald et al., 2004; Huang et al., 2006). However, there have only been a few reports of its effects on soil microbial community structure in the presence of growing plants. In our experiment, the soil microbial community structure was significantly different in the CK treatment from that in the NR, PE and SK treatments during the middle growth period of celery. Most of these PLFAs represent either Gram-negative bacteria (Wilkinson, 1988) or fungi (Frostegard and Baath, 
1996). Nitrogen competitions exists among soil microorganisms and plants during the growing season when soil $\mathrm{N}$ availability is low, leading to $\mathrm{N}$ limitation for soil microorganisms (Zak et al., 1990; Hines et al., 2006). At $49 \mathrm{~d}$ after fertilization, total $\mathrm{N}, \mathrm{NO}_{3}{ }^{-}$and $\mathrm{NH}_{4}{ }^{+}$showed no significant differences between the $\mathrm{CK}$ treatment and the other treatments. However this does not imply that $\mathrm{N}$ was not limited in the CK treatment. Some work has shown that monounsaturated PLFAs and fungi indexed PLFAs increased under starvation conditions such as $\mathrm{N}$ limitation (Heipieper et al., 1996; Traore et al., 2016), consistent with the current results. Du et al. (2018) found that the abundance of soil bacteria (including nitrifiers and denitrifiers), fungi, and actinomycetes increased with increased $\mathrm{N}$ application in greenhouse celery production.

After the celery was harvested, the soil microbial community structure in the PE treatment differed significantly from those in the other three treatments. Compared with the other treatments, the PE treatment had a higher concentration of Gram-positive bacteria (Wilkinson, 1988), and a lower concentration of Gram-negative bacteria and fungi (Frostegard and Baath, 1996; Mutabaruka et al., 2007). Calcium cyanamide used in the PE treatment increased soil $\mathrm{pH}$ and supplied enough $\mathrm{N}$ during the whole growth period of the celery. However, as, after $49 \mathrm{~d}$ fertilization, there was no significant difference in the soil microbial community structure between the PE, NR and SK treatments, we are unable to prove that the differences in PLFA profiles after $78 \mathrm{~d}$ fertilization were due to the changes in the soil $\mathrm{pH}$ and $\mathrm{N}$ content. Besides, the side effects of calcium cyanamide on the majority of microorganisms are negligible after $15 \mathrm{~d}$ (Shi et al., 2009). Therefore, the differences are unlikely to be caused directly by toxicity induced by the degradation of calcium cyanamide. There was no significant difference in the growth of celery in any of the treatments from $49 \mathrm{~d}$ after fertilization. The yield was obviously higher in the PE treatment than in the other treatments at $78 \mathrm{~d}$ after fertilization. As about $40 \%$ of plant photosynthates are released into soil from the roots (Lynch and Whipps, 1991), there should be higher nutrient availability in the rhizosphere region of soil in the $P E$ treatment. Differences in the amount of root exudates will affect the survival of different microbial species (Marschner and Timonen, 2006). This might be why the soil microbial community structure is different in the PE treatment compared to the other treatments.

\section{Conclusions}

We have shown that application of different $\mathrm{N}$ fertilizers had different effects on celery yield, soil properties and microbial communities. Calcium cyanamide application significantly increased celery yield, soil $\mathrm{pH}$ and soil microbial biomass $\mathrm{C}$, and altered the soil microbial community. Our results suggest that calcium cyanamide is a potential alternative to $\mathrm{N}$ fertilizer in acidified vegetable soils. Further work is required to elucidate the subtle changes in detailed species related nutrient cycling and soil-borne diseases using high-resolution techniques.

\section{Acknowledgments}

This work was financially supported by the Ningbo Agricultural Science and Education Project (2013NK29) and the National Natural Science Foundation of China (41301251).

\section{Electronic supplementary material}

Supplementary material is available in the online version of this article at http://dx.doi.org/10.1007/s42832-019-0012-z and is accessible for authorized users.

\section{References}

Amberger, A., Vilsmeier, K., 1979. Inhibition of the nitrification of liquid manure nitrogen by dicyandiamide. Zeitschrift Fur Acker Und Pflanzenbau-Journal of Agronomy and Crop Science 148, 239246.

Arora, Y., Singh, L., Nnadi, L.A., 1987. Transformation of calcium cyanamide and its inhibitory effect on urea nitrification in some tropical soils. Fertilizer Research 12, 3-9.

Bao, S.D., 1999. Analytical Methods of Soil Agrochemistry (in Chinese). China Agricultural Press, Beijing.

Bourbos, V.A., Skoudridakis, M.T., Darakis, G.A., Koulizakis, M., 1997. Calcium cyanamide and soil solarization for the control of Fusarium solani f. sp. cucurbitae in greenhouse cucumber. Crop Protection (Guildford, Surrey) 16, 383-386.

Brookes, P.C., Landman, A., Pruden, G., Jenkinson, D.S., 1985. Chloroform fumigation and the release of soil-nitrogen- a rapid direct extraction method to measure microbial biomass nitrogen in soil. Soil Biology \& Biochemistry 17, 837-842.

Cai, Z.J., Wang, B.R., Xu, M.G., Zhang, H.M., He, X.H., Zhang, L., Gao, S.D., 2015. Intensified soil acidification from chemical $N$ fertilization and prevention by manure in a 18-year field experiment in the red soil of southern China. Journal of Soils and Sediments 15, 260-270.

Crowther, E.M., Richardson, H.L., 1932. Studies on calcium cyanamide. I. The decomposition of calcium cyanamide in the soil and its effects on germination, nitrification and soil reaction. Journal of Agricultural Science 22, 300-334.

Donald, E.C., Lawrence, J.M., Porter, I.J., 2004. Influence of particle size and application method on the efficacy of calcium cyanamide for control of clubroot of vegetable brassicas. Crop Protection (Guildford, Surrey) 23, 297-303.

Du, Y.D., Niu, W.Q., Zhang, Q., Cui, B.J., Gu, X.B., Guo, L.L., Liang, B. $H$., 2018. Effects of nitrogen on soil microbial abundance, enzyme activity, and nitrogen use efficiency in greenhouse celery under aerated irrigation. Soil Science Society of America Journal 82, 606-613.

El-Sayed, S.M., Glala, A.A., Adam, M., 2011. Response of two celery 
cultivars to partial organic nitrogen alternation strategies. Australian Journal of Basic and Applied Sciences 5, 22-29.

Frostegard, A., Baath, E., 1996. The use of phospholipid fatty acid analysis to estimate bacterial and fungal biomass in soil. Biology and Fertility of Soils 22, 59-65.

Gu, N., Zhao, L.P., Zhao, X.M., 2014. A review and perspective on slow and controlled release fertilizer in China. Applied Mechanics and Materials 535, 222-225.

Guo, J.H., Liu, X.J., Zhang, Y., Shen, J.L., Han, W.X., Zhang, W.F., Christie, P., Goulding, K.W.T., Vitousek, P.M., Zhang, F.S., 2010. Significant acidification in major Chinese croplands. Science 327 , 1008-1010.

Heipieper, H.J., Meulenbeld, G., van Oirschot, Q., de Bont, J., 1996. Effect of environmental factors on the trans/cis ratio of unsaturated fatty acids in Pseudomonas putida S12. Applied and Environmental Microbiology 62, 2773-2777.

Hines, J., Megonigal, J.P., Denno, R.F., 2006. Nutrient subsidies to belowground microbes impact aboveground food web interactions. Ecology 87, 1542-1555.

Huang, H.C., Erickson, R.S., Phillippe, L.M., Mueller, C.A., Sun, S.K., Huang, J.W., 2006. Control of apothecia of Sclerotinia sclerotiorum by soil amendment with S-H mixture or Perlka $(\mathrm{R})$ in bean, canola and wheat fields. Soil Biology \& Biochemistry 38, 1348-1352.

Ju, X.T., Kou, C.L., Christie, P., Dou, Z.X., Zhang, F.S., 2007. Changes in the soil environment from excessive application of fertilizers and manures to two contrasting intensive cropping systems on the North China Plain. Environmental Pollution 145, 497-506.

Li, Y.Y., Wang, J., Pan, F.X., Chapman, S.J., Yao, H.Y., 2016. Soil nitrogen availability alters rhizodeposition carbon flux into the soil microbial community. Journal of Soils and Sediments 16, 14721480.

Li, Z., Wang, Y., Liu, Y., Guo, H., Li, T., Li, Z.H., Shi, G., 2014. Longterm effects of liming on health and growth of a Masson pine stand damaged by soil acidification in Chongqing, China. PLoS One 9, e94230.

Liang, L.Z., Zhao, X.Q., Yi, X.Y., Chen, Z.C., Dong, X.Y., Chen, R.F., Shen, R.F., 2013. Excessive application of nitrogen and phosphorus fertilizers induces soil acidification and phosphorus enrichment during vegetable production in Yangtze River Delta, China. Soil Use and Management 29, 161-168.

Lucas, R.W., Klaminder, J., Futter, M.N., Bishop, K.H., Egnell, G., Laudon, H., Hogberg, P., 2011. A meta-analysis of the effects of nitrogen additions on base cations: Implications for plants, soils, and streams. Forest Ecology and Management 262, 95-104.

Lynch, J.M., Whipps, J.M., 1991. Substrate flow in the rhizosphere. In: Keister, D.L., Cregan, B. (Eds) The rhizosphere and plant growth (Beltsville symposia in agricultural research). Kluwer Academic Publishers, Dordrecht, pp. 15-24.

Marschner, P., Kandeler, E., Marschner, B., 2003. Structure and function of the soil microbial community in a long-term fertilizer experiment. Soil Biology \& Biochemistry 35, 453-461.

Marschner, P., Timonen, S., 2006. Bacterial community composition and activity in rhizospheres of roots colonized by arbuscular mycorrhizal fungi. In: Mukerji, K.G., Manoharachary, C., Singh, J. (Eds) Microbial acitivity in the rhizosphere. Springer, Berlin, pp. 139-154.
Matschonat, G., Matzner, E., 1996. Soil chemical properties affecting $\mathrm{NH}_{4}{ }^{+}$sorption in forest soils. Zeitshrift fur Pflanzenernahrung und Bodenkunde 159, 505-511.

Mukerji, B.K., 1932. Studies on calcium cyanamide II. Microbiological aspects of nitrification in soils under varied environmental conditions. Journal of Agricultural Science 22, 335-347.

Mutabaruka, R., Hairiah, K., Cadisch, G., 2007. Microbial degradation of hydrolysable and condensed tannin polyphenol-protein complexes in soils from different land-use histories. Soil Biology \& Biochemistry 39, 1479-1492.

Noble, A.D., Zenneck, I., Randall, P.J., 1996. Leaf litter ash alkalinity and neutralisation of soil acidity. Plant and Soil 179, 293-302.

Oh, K., Kato, T., Li, Z.P., Li, F.Y., 2006. Environmental problems from tea cultivation in Japan and a control measure using calcium cyanamide. Pedosphere 16, 770-777.

Ruan, J., Ma, L., Yang, Y., 2012. Magnesium nutrition on accumulation and transport of amino acids in tea plants. Journal of the Science of Food and Agriculture 92, 1375-1383.

Shand, C.A., Williams, B.L., Coutts, G., 2008. Determination of Nspecies in soil extracts using microplate techniques. Talanta 74 , 648-654.

Shi, K., Wang, L., Zhou, Y.H., Yu, Y.L., Yu, J.Q., 2009. Effects of calcium cyanamide on soil microbial communities and Fusarium oxysporum f. sp. cucumberinum. Chemosphere 75, 872-877.

Thornton, B., Zhang, Z., Mayes, R.W., Högberg, M.N., Midwood, A.J., 2011. Can gas chromatography combustion isotope ratio mass spectrometry be used to quantify organic compound abundance? Rapid Communications in Mass Spectrometry 25, 2433-2438.

Tian, D.S., Niu, S.L., 2015. A global analysis of soil acidification caused by nitrogen addition. Environmental Research Letters 10, 024019.

Tian, Y.Q., Zhang, X.Y., Liu, J., Chen, Q., Gao, L.H., 2009. Microbial properties of rhizosphere soils as affected by rotation, grafting, and soil sterilization in intensive vegetable production systems. Scientia Horticulturae 123, 139-147.

Traore, O.Y.A., Kiba, D.I., Arnold, M.C., Fliessbach, A., Oberholzer, H. R., Nacro, H.B., Lompo, F., Oberson, A., Frossard, E., Bunemann, E.K., 2016. Fertilization practices alter microbial nutrient limitations after alleviation of carbon limitation in a Ferric Acrisol. Biology and Fertility of Soils $52,177-189$.

Van der Bom, F., Nunes, I., Raymond, N.S., Hansen, V., Bonnichsen, L., Magid, J., Nybroe, O., Jensen, L.S., 2018. Long-term fertilisation form, level and duration affect the diversity, structure and functioning of soil microbial communities in the field. Soil Biology \& Biochemistry 122, 91-103.

Wang, C., Liu, D.W., Bai, E., 2018. Decreasing soil microbial diversity is associated with decreasing microbial biomass under nitrogen addition. Soil Biology \& Biochemistry 120, 126-133.

Wells, A.T., Chan, K.Y., Cornish, P.S., 2000. Comparison of conventional and alternative vegetable farming systems on the properties of a yellow earth in New South Wales. Agriculture, Ecosystems \& Environment 80, 47-60.

Wilkinson, S.G., 1988. Gram-negative bacteria. In: Ratledge, C., Wilkinson, S.G. (Eds). Microbial Lipids. Academic Press, London, pp. $299-408$.

Wu, J., Joergensen, R.G., Pommerening, B., Chaussod, R., Brookes, 
P.C., 1990. Measurement of soil microbial biomass $\mathrm{c}$ by fumigation extraction- an automated procedure. Soil Biology \& Biochemistry 22, 1167-1169.

Xiao, W.L., Wang, Z.X., Wu, F.Z., Zhou, X.G., 2018. Effects of soil improvement technology on soil quality in solar greenhouse. Environmental Science and Pollution Research International 25, 24093-24100.

Xiong, Y.S., Yuan, J.F., Hu, R.G., 2010. The influence of coated urea on yield and quality of vegetable crops and nitrogen balance in calcareous Chao soil. Journal of Food Agriculture and Environment 8, 655-659.

Yamamoto, A., Akiyama, H., Naokawa, T., Miyazaki, Y., Honda, Y., Sano, Y., Nakajima, Y., Yagi, K., 2014. Lime-nitrogen application affects nitrification, denitrification, and $\mathrm{N}_{2} \mathrm{O}$ emission in an acidic tea soil. Biology and Fertility of Soils 50, 53-62.

Yang, L., Huang, B., Mao, M., Yao, L., Niedermann, S., Hu, W., Chen, Y., 2016. Sustainability assessment of greenhouse vegetable farming practices from environmental, economic, and socioinstitutional perspectives in China. Environmental Science and Pollution Research International 23, 17287-17297.

Zak, D.R., Groffman, P.M., Pregitzer, K.S., Christensen, S., Tiedje, J. M., 1990. The Vernal Dam- plant microbe competition for nitrogen in northern hardwood forests. Ecology 71, 651-656.

Zhang, M.M., Wang, B.R., Li, D.C., He, J.Z., Zhang, L.M., 2015. Effects of long-term $\mathrm{N}$ fertilizer application and liming on nitrification and ammonia oxidiers in acidic soils. Acta Ecologica Sinica 35, 6362-6370.

Zhang, N.L., Wan, S.Q., Li, L.H., Bi, J., Zhao, M.M., Ma, K.P., 2008. Impacts of urea $\mathrm{N}$ addition on soil microbial community in a semiarid temperate steppe in northern China. Plant and Soil 311, 19-28.

Zhou, Z., Wang, C., Zheng, M., Jiang, L., Luo, Y., 2017. Patterns and mechanisms of responses by soil microbial communities to nitrogen addition. Soil Biology \& Biochemistry 115, 433-441. 